\title{
The effects of a self-regulatory approach on the listening comprehension achievement of EFL learners
}

Latifi, Mehdi $₫$

University of Isfahan, Iran (Smm_latifi@yahoo.com)

Tavakoli, Mansoor

University of Isfahan, Iran (Mr.tavakoli@gmail.com)

Dabaghi, Azizollah

University of Isfahan, Iran (dabaghi@ui.ac.ir)

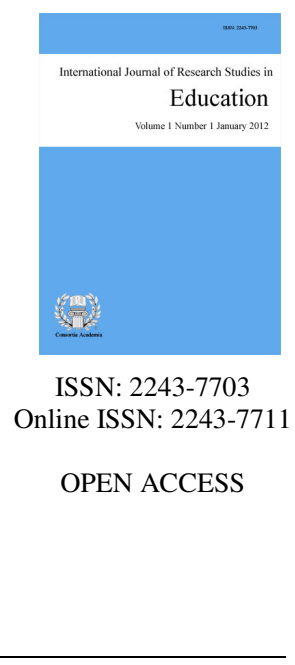

\section{Abstract}

The present study investigated the effectiveness of a self-regulatory approach on the improvement of listening comprehension ability of EFL learners. Ninety EFL Persian-speaking learners in three language centers constituted the five groups of this study being; One High-Skilled Unedited Movie Group (HUMG), one Low-Skilled Unedited Movie Group (LUMG), one High-Skilled Pedagogical Movie Group (HPMG), one Low-Skilled Pedagogical Movie Group (LPMG), and a Control Group (CG). The results of the posttest indicated that there was a significant difference between all groups, and that the treatment was considerably effective. The High and Low Skilled groups outperformed the other group being the Control Group, on the posttest. Besides, although there were no significant differences between the High and Low Skilled learners on the post test, the Low Skilled learners had the most significant improvement. The findings of this study also revealed that training language learners via unedited movies may lead to more noticeable progress compared to pedagogical movies.

Keywords: high skilled listeners; low skilled listeners; listening comprehension; self-regulatory approach 


\section{The effects of a self-regulatory approach on the listening comprehension achievement of EFL learners}

\section{Introduction}

Teaching listening comprehension does not receive the attention it deserves, and students do not seem to be appropriately trained by up-to-date methods of teaching listening comprehension such as strategy instruction. According to Mareschal (2007), in lots of language learning contexts, second language learners are still expected to acquire listening skills by mere exposure and on their own (without any guidance). As Oxford (2011) mentioned, most listening classes are merely a test of listening rather than teaching. Listening classes nowadays are "a conventional listening comprehension lesson that simply adds yet another text to the learners' experience; it does little or nothing to improve the effectiveness of their listening, or to address their shortcomings as listeners" (Mareschal, 2007, p. 35).

The problems that listeners encounter during the listening task are dealt with in the form of merely translating problematic parts; however, no attention is paid to teaching the process of listening which is the source of most of listening difficulties. Training language learners to cope with their own process of learning (self-regulation) can have a major impact on the improvement of their listening ability. Cohen (2000) posits that "language learning and use of strategies can have a major role in helping shift the responsibility for learning off the shoulders of the teachers and onto those of learners (p. 21)". However, a drawback of a mere cognitive and metacognitive instruction as mentioned by Cohen and Macaro (2007) is neglecting meta-affective and affective strategies in the treatment process. In the past, the affective dimension of language learning was almost overlooked in language classes (Jensen \& Vinther, 2003; Vaez, Dalili, \& Tavakoli, 2013). Oxford (2011) points out that a metacognitive approach should try to give the learner a deeper understanding of themselves as someone who is learning another language and faces many challenges. Besides, they must be taught how to handle their comprehension and the process of learning in general.

To address this problem, Oxford (2011) presented a comprehensive model of self-regulation entitled "Strategic Self-Regulation model" (Henthforth, $S^{2} \mathrm{R}$ ) which can look into different aspects of learning. This model of teaching forms the theoretical framework of the present study. Oxford's model performs on two levels. One strategic level which includes exploiting cognitive, affective and socio-cultural strategies, accompanied by a meta-strategy level which takes into consideration Metacognitive, Meta-affective, and Meta-sociocultural-interactive strategies. Students who are trained in this way will be able to select appropriate strategies based on their goals, and evaluate the success of these strategies. Learners can use strategies to regulate many aspects of their learning: their internal mental states, beliefs, observable behaviors, and the learning environment (Oxford, 2011; Fatemi \& Vahidnia, 2014). This study, therefore, is going to incorporate the $\mathrm{S}^{2} \mathrm{R}$ model to improve L2 earners listening comprehension more efficiently and train them to be more independent.

A self-regulatory approach can also be beneficial to students particularly in the form of improved motivation and better management of their learning. It is emphasized that independent learning does not merely involve students working alone but stresses the important role teachers can play in enabling and supporting independent learning. Oxford suggests that successful independent learning depends on a number of factors. These include cognitive skills such as focusing of memory, attention and problem-solving, metacognitive skills associated with an understanding of how learning occurs along with affective skills related to feelings and emotions. A teaching approach should try to give L2 learners a deeper understanding of themselves as someone who is learning another language.

Given the mentioned problem, this study implemented the $S^{2} R$ model to include all the required factors for a 
more efficient training program. An attempt was made to develop some more efficient leaders' learners who can be in charge of their learning process via a self-regulatory approach. In the following section, a brief review of literature will be presented and important articles will be discussed to elaborate more on the issue and the studies conducted.

\section{The literature Review}

During the recent years some scholars have investigated different aspects of strategy instruction on the language learners listening comprehension achievements. These studies range from some fundamental areas such as defining the construct of strategies (Cohen, 2007), to more practical issues such as figuring out the ways in which strategy instruction can help out the process of second language acquisition and produce more efficient and skilled language listeners. Since listening comprehension is an importance source in providing input to learners, improving the listening comprehension of language learners has been the major concern of some second language experts.

In this regard, an article was published which was considered as the birth of language learner strategy research written by Joan Rubin (1975) entitled 'what the good language learner can teach us'. This article was about the techniques and approaches which were used by successful language learners. Later, Joens, Palinscar, Ogle, and Carr (1987) put emphasis on the importance of developing some independent language learners who can manage their language learning processes. They found that successful and highly motivated learners used more strategies compared to poor motivated language learners.

In order to find the problems of second language listeners, Goh $(2000,2002)$ conducted a survey on poor listening comprehension skills.Tthe subjects took part in a semi-structured interview and kept journal of the problems they had. Then they participated in some small group interviews. At the end of the study, she found out that, generally, listeners (i) forget things very fast, (ii) can't build up a mental representation of what was said, and finally (iii) lose track of the listening text because of the aforementioned problems. In sum, the subjects' problems were two-fold. First they could not recall the words they had learnt before, and then they would quickly forget what was said in a passage. It was also found that less skilled listeners would focus on the meaning of a single unknown word and lose track of the rest of the text. The survey followed Anderson's (1985) model regarding perceptual processing, parsing and utilization.

In addition, scholars noticed that the problem with second language listeners is not only the strategy use; but also their inability to orchestrate the learnt strategies. Consequently, the focus of studies was directed towards meta-cognitive strategies since language acquisition research has discovered that meta-cognitive strategies and regular trainings can improve listeners' consciousness of listening processes (Goh, 2008). Raising consciousness in this way can assist listeners to predict, monitor, and evaluate their listening process, and therefore, enable them to improve their listening comprehension ability in general (Goh, 2002; Vandergrift, 2003).

Among the very first studies conducted on the effectiveness of meta-cognitive strategies on improving listening comprehension is the study conducted by O'Malley and Chamot (1990). There were three groups in this study: the group that received instruction in meta-cognitive, cognitive, and socio-affective strategies, the group that received instruction in cognitive and socio-affective strategies only, and finally the control group that received no strategy instruction. The results of the study revealed that the performance of the participants of "group one" on the tests was significantly better than the other groups in terms of listening comprehension improvement. The second group which received cognitive and socio-affective strategy came in second and the control group was ranked last. Moreover, Vandergrift (1997) found that "when listeners use strategies with different types of listening tasks, the total number of strategies as well as the number of distinct meta-cognitive strategies increased by course level' (p. 18).

Goh (2000) has also found that by growing listeners' knowledge of meta-cognitive strategies, they will be more autonomous in solving their listening problems and that they won't give up the listening task very fast any 
more. Another study that supported the importance of meta-cognitive strategies in second language acquisition is Vandergrift (2002). In this study, it was found that the exploitation of meta-cognitive strategies (for example, prediction and evaluation) has the capacity of leading listeners to success in L2 listening tasks. According to the findings, Vandergrift mentioned that the success achieved in a particular task can be extended to future tasks and that listeners will learn how to autonomously work out more comprehension in their future listening tasks (Vandergrift, 2003).

Vandergrift and Tafaghodtari (2010), in addition, investigated the effects of a meta-cognitive, process-based approach to teaching second language (L2) listening over a semester. Participants listened to some texts using a methodology that led learners through meta-cognitive processes (prediction/planning, monitoring, evaluating, and problem solving) underlying successful L2 listening. Development of metacognition about L2 listening was measured by the Meta-cognitive Awareness Listening Questionnaire (MALQ). However, despite the reasonable number of studies on the effect of meta-cognitive instruction on listening comprehension, few studies have dealt with the effect of self-regulation in listening comprehension.

Vandergrift et al. (2006), for instance, in his study came up with the conclusion that listening tasks which help students deal with the process of listening, by involving them in the different stages of prediction, monitoring, evaluation and problem-solving, can assist listeners to develop the meta-cognitive and strategic knowledge essential for developing a self-regulated listener. Mareschal (2007) also studied the effect of self-regulation and meta-cognitive strategy instruction on some low and high intermediate French language learners during 8 weeks of language training program. The results of data analysis by using a listening questionnaire (MALQ), stimulated-recall protocols, diaries, think-aloud protocols, and a final summative open-ended questionnaire, revealed that the students benefited from the metacognitive strategy instructions and were able to self-regulate themselves better during the listening task; therefore, their listening comprehension ability improved. Except few studies mentioned above, studies on the self-regulatory approach to teaching listening comprehension are few and far between; hence, there is a need for more comprehensive pieces of research in different contexts.

\subsection{Significance of the Study}

Metacognitive instruction, despite the popularity gained, suffers from some theoretical drawbacks. According to Cohen (2007), a metacognitive approach does not pay enough attention to other equally important aspects of language learning being social and affective. Based on the recent self-regulatory model proposed by Oxford (2011), these two factors were also taken into account. This is an improvement over the current approaches of teaching listening comprehension. It is claimed that by implementing a self-regulatory model of teaching, L2 listeners can benefit more from trainings compared to the existing methods of teaching listening comprehension (Oxford, 2011). However, to the researchers' knowledge, few (if any) studies have put Oxfords' self-regulatory model $\left(\mathrm{S}^{2} \mathrm{R}\right)$ into practice to capture its effects on teaching listening comprehension. Hence, this study is going to address this gap which attached significance to the present study to be carried out. Some independent language listeners can be developed via a self-regulatory approach that can take charge of their learning process and improve their language proficiency on their own. This independence on behalf of language learners is the ultimate goal of most teaching method; the results of this study, therefore, can contribute to the field of language teaching in general and listening comprehension in particular.

A part from the method of teaching listening comprehension, the material through which language learners are being exposed to English in language classes is of great importance. The issue that is most problematic for language learners is their inability to comprehend the natural flow of information (Latifi, Youhanaee, \& Mohammadi, 2013). This lack of comprehension makes them frustrated and they easily give up listening to the rest of the text. There has been an ongoing debate among scholars whether to incorporate some unedited English movies or some edited listening materials designed for L2 learners (Vandergrift, 2003). The present study, therefore, is going to investigate this issue and use some unedited listening materials to see if it can help L2 listeners alleviate their fear of being exposed to real-life communications and improve their comprehension. 
The effects of a self-regulatory approach on the listening comprehension achievement of EFL learners

Such findings can be of great significance for both curriculum developers and language teachers.

\subsection{Research Questions}

$>\quad$ What are the effects of a self-regulatory approach on the listening comprehension achievement of High and Low Skilled learners in Iran?

$>\quad$ What are the effects of a self-regulatory approach on the listening achievement of language learners in dealing with unedited listening materials?

\subsection{Research Hypotheses}

$>\quad$ There are no effects for a self-regulatory approach on the listening comprehension achievement of High and Low Skilled learners in Iran.

$>\quad$ There are no differences in the listening comprehension improvement of high and Low skilled learners using Unedited listening materials.

\subsection{Participants}

Ninety English language learners (out of 359) were selected by means of a listening section of an IELTS test to carry out the present study. The average grade point of all test takers on the IELTS test was calculated and those who fell in the range of one standard deviation below and above the mean were chosen to be a part of the study. Those who scored more than +.5 to one standard deviation above the mean were considered as high skilled and those who scored more than -.5 to one standard deviation below the mean were assigned into the low skilled groups. Then they were assigned into 5 groups: one High-Skilled Unedited Movie Group (HUMG), one Low-Skilled Unedited Movie Group (LUMG), one High-Skilled Pedagogical Movie Group (HPMG), one Low-Skilled Pedagogical Movie Group (LPMG), and a Control Group (CG). The Control Group had a combination of high and low skilled learners. Each group had 15 participants while the Control Group had 30 students to have equal number of low and high skilled learners like the other groups and even the numbers up in the final data analysis. The participants were mostly between the age-range of 16 to 25 . They were all selected from Sadr, Basir and Kaj language centers in Isfahan.

\section{Methodology}

Ninety male and female English language learners (out of 359) were selected by means of a Listening section of an IELTS test and were assigned into 5 groups. As for the materials, Ice Age movies (3 and 4) were the focus of listening exercises, for periods of approximately 45 minutes, three times a week during a 10-week semester. The unedited movies were segmented to vary in length from 9 to 11 minute long. The pedagogical movies were taken from Four Corner book series (the Intermediate level, book 3 and 4). The subjects were required to watch their related movies without any preparations due to the fact that the same thing happens in real life situations (Vandergrift, 2007). The normal training was given to the learners for all 5 groups.

First, before listening to the text, the students were instructed to think about the best possible ways to deal with approaching the listening tasks. For instance, the teacher would model a strategy like how to predict what comes next. They were also instructed not to pay attention to every single word while listening and to try to get a general idea of the listening text. Then for the first listen, the selected part would be played uninterrupted. After that, the students would be required to write down the general points that they had managed to understand, and the factors that their comprehension was based on.

After that, the listening text was played for a second time uninterrupted. Similar to the first listen, the subjects were asked to write down their understanding of the text, how they could understand it, were there any changes compared to their first listen and why? Besides, they were asked to mention the points that they wanted 
to look for or pay attention to in the third listen. Then the students would discuss, in English or Persian and with their partners, the problems that they had in the understanding of the text, and the ways that they used to resolve their problems. Finally, they would discuss how to approach the third listen.

The text would be played for the third time (uninterrupted). Similar to the previous listens, they would watch the related movies and share their understanding and problems either in Persian or English. They were required to talk about the ways that they solved their problems and what their idea was about the different techniques that were deployed in this regard. They were also asked to write the useful points which were discussed in the class. In the post listening activities, some strategies were emphasized on and presented by the teacher as a model, for instance:

$>$ Remember to focus attentively throughout the listen

$>$ Remember not to focus excessively on individual segments.

$>$ Resist the temptation to translate literally while listening.

$>$ Remember to systematically question and double-check any unfamiliar expression which had been guessed, and to draw from a variety of sources of back ground knowledge you have for comprehension.

At the end of the study, the post test was administered. The same steps were also followed for the control groups, except for the direct and conscious explanations and verbalizations of the strategies. They would watch the movie, discuss them and work on the scripts, but no strategy instruction was involved.

\section{Data Analysis}

\subsection{The effects of the self-regulatory approach}

The first hypothesis states that there are no effects for a self-regulatory approach on the listening comprehension achievement of High and Low Skilled learners. In order to investigate the impacts of the self-regulatory approach on the subjects' performance on listening comprehension tests, first, the researchers conducted a one way ANCOVA as the participants were not homogeneous in the beginning of the treatment. After that, a follow up one way ANOVA for the Posttest was conducted to find the direction of the differences. Group statistics and the results are presented below.

\section{Table 1}

Levene's Test of Equality for ANCOVA on the Posttest

\begin{tabular}{cccc}
\hline $\mathrm{F}$ & $\mathrm{df} 1$ & $\mathrm{df} 2$ & Sig. \\
\hline 2.187 & 4 & 85 & .077 \\
\hline
\end{tabular}

The details in the table labeled Levene's Test of Equality of Error Variances allow you to check that you have not violated the assumption of equality of variance. The table indicates that the assumption has not been violated because our significance value is.077, which is much larger than our cut-off of .05. One-way between-groups analysis of covariance was conducted to compare the effectiveness of the self-regulatory approach on the listening comprehension ability of learners. The independent variable was the type of intervention (self-regulatory approach) and the dependent variable consisted of scores of the IELTS test administered after the intervention immediately. Participants' scores on the pre intervention administration of the IELTS test were used as the covariate in the analysis. After adjusting for pre-intervention scores, there was a significant difference between the intervention groups on post-intervention scores, $\mathrm{F}(4,84)=31.04, p=.000$. There was a strong relationship between the pre-intervention and post-intervention scores. 
The effects of a self-regulatory approach on the listening comprehension achievement of EFL learners

Table 2

Tests of Between-Subjects Effects of ANCOVA on the Posttest

\begin{tabular}{llllcccc}
\hline & \multicolumn{2}{l}{ Type III Sum of } & & & & Partial & Eta \\
Source & Squares & $d f$ & Mean Square & $F$ & Sig. & Squared \\
\hline Corrected Model & $13.590^{\mathrm{a}}$ & 5 & 2.718 & 28.815 & .000 & .632 \\
Intercept & 7.634 & 1 & 7.634 & 80.930 & .000 & .491 \\
Pretest & 2.843 & 1 & 2.843 & 30.141 & .000 & .264 \\
Groups & 11.715 & 4 & 2.929 & 31.049 & .000 & .597 \\
Error & 7.924 & 84 & .094 & & & & \\
Total & 3413.250 & 90 & & & & & \\
Corrected Total & 21.514 & 89 & & & &
\end{tabular}

Based on the table, the first null hypothesis was rejected as the results of the ANCOVA indicated an improvement rate for the experimental groups. A follow up ANOVA was conducted to have a more detailed analysis of the groups. The results will be discussed in the following section.

\subsection{Group differences on the posttest}

A one way ANOVA for the posttest together with Tukey post hoc analyses was conducted in order to capture the differences of all groups after the treatment. The results are demonstrated in tables 3 , and 4 . The analysis of data, as shown in Table 3, revealed that there was a statistically significant difference at the $p<.05$ level in IELTS scores for the five groups $[\mathrm{F}(4,85)=21.21, p=.000]$.

Table 3

ANOVA for the Posttest for All Groups

\begin{tabular}{lllllll}
\hline & Sum of Squares & $d f$ & Mean Square & $F$ & Sig. \\
\hline Posttest & Between Groups & 10.747 & 4 & 2.687 & 21.212 & .000 \\
& Within Groups & 10.767 & 85 & .127 & & \\
& Total & 21.514 & 89 & & & \\
\hline
\end{tabular}

On the post test, the Tukey HSD post-hoc comparisons indicated that there were no significant differences between the mean scores for the High-skilled Unedited Movie Group and Low-skilled Unedited Movie Group $(\mathrm{F}=.666$ and $p=.984$ )and also High Skilled Pedagogical Movie Group ( $\mathrm{F}=.256$ and $p=.356)$. High-skilled Unedited Movie Group, on the other hand, performed statically better compared to the Low-skilled Pedagogical Movie Group $(\mathrm{F}=.400$ and $p=.018)$ and the Control Group $(\mathrm{F}=.816$ and $p=.000)$. The Low-skilled Unedited Movie Group also had similar pattern $(\mathrm{F}=.4066$ and $p=.004$ for the LSPMG and $\mathrm{F}=.883$ and $p=.000$ for the CG). High and Low-skilled Pedagogical Movie Groups had merely a statistically better mean difference compared to the Control Group by $\mathrm{F}=.5833$ and $p=.000$ and $\mathrm{F}=.4166$ and $p=.002$ respectively.

\subsection{The effect of movie types}

The 2nd null hypothesis states that there is no difference between using unedited and pedagogical listening materials in terms of their effects on the listening comprehension of EFL learners. An independent sample t-test was run in this regard. Group statistics and the results of the t-test are presented in Tables, 5 and table 6 , respectively. Given the information in Table 5, one can clearly see that the mean score obtained on the post-test for the unedited movie learners (6.53) is higher than the one obtained on the post-test for the pedagogical movie learners (6.18). However, an independent sample t-test was run to ensure that the observed differences were significant. 
Latifi, M., Tavakoli, M., \& Dabaghi, A.

\section{Table 4}

Tukey Post hoc Analysis for the Posttest and the Delayed Posttest for All Groups

\begin{tabular}{|c|c|c|c|c|c|}
\hline $\begin{array}{l}\text { Dependent } \\
\text { Variable }\end{array}$ & $\begin{array}{l}\text { (I) Self Regulatory } \\
\text { Approach Groups }\end{array}$ & $\begin{array}{l}\text { (J) Self Regulatory } \\
\text { Approach Groups }\end{array}$ & $\begin{array}{l}\text { Mean } \\
\text { Difference } \\
(\mathrm{I}-\mathrm{J})\end{array}$ & Std. Error & Sig. \\
\hline \multirow[t]{8}{*}{ Posttest } & $\begin{array}{l}\text { High-skilled Unedited } \\
\text { Movie Group }\end{array}$ & $\begin{array}{l}\text { Low-skilled Unedited } \\
\text { Movie Group }\end{array}$ & -.06667 & .12654 & .984 \\
\hline & & $\begin{array}{l}\text { High-skilled Pedagogical } \\
\text { Movie Group }\end{array}$ & .23333 & .12654 & .356 \\
\hline & & $\begin{array}{l}\text { Low-skilled Pedagogical } \\
\text { Movie Group }\end{array}$ & $.40000^{*}$ & .12654 & .018 \\
\hline & & Control Group & $.81667^{*}$ & .10959 & .000 \\
\hline & $\begin{array}{l}\text { Low-skilled Unedited } \\
\text { Movie Group }\end{array}$ & $\begin{array}{l}\text { High-skilled Unedited } \\
\text { Movie Group }\end{array}$ & .06667 & .12654 & .984 \\
\hline & & $\begin{array}{l}\text { High-skilled Pedagogical } \\
\text { Movie Group }\end{array}$ & .30000 & .12654 & .133 \\
\hline & & $\begin{array}{l}\text { Low-skilled Pedagogical } \\
\text { Movie Group }\end{array}$ & $.46667^{*}$ & .12654 & .004 \\
\hline & & Control Group & $.88333^{*}$ & .10959 & .000 \\
\hline
\end{tabular}

\section{Table 5}

T-Test Group statistics for the scores of the pedagogical and Unedited Movie Groups on the Posttest

\begin{tabular}{llllll}
\hline & Movie & $N$ & Mean & Std. Deviation & Std. Error Mean \\
\hline \multirow{2}{*}{ Posttest } & Unedited & 30 & 6.5333 & .18257 & .03333 \\
& Edited & 30 & 6.1833 & .30747 & .05614 \\
\hline
\end{tabular}

Table 6

Independent Samples T-Test results for the scores of the pedagogical \& Unedited Movie Groups on the Posttest

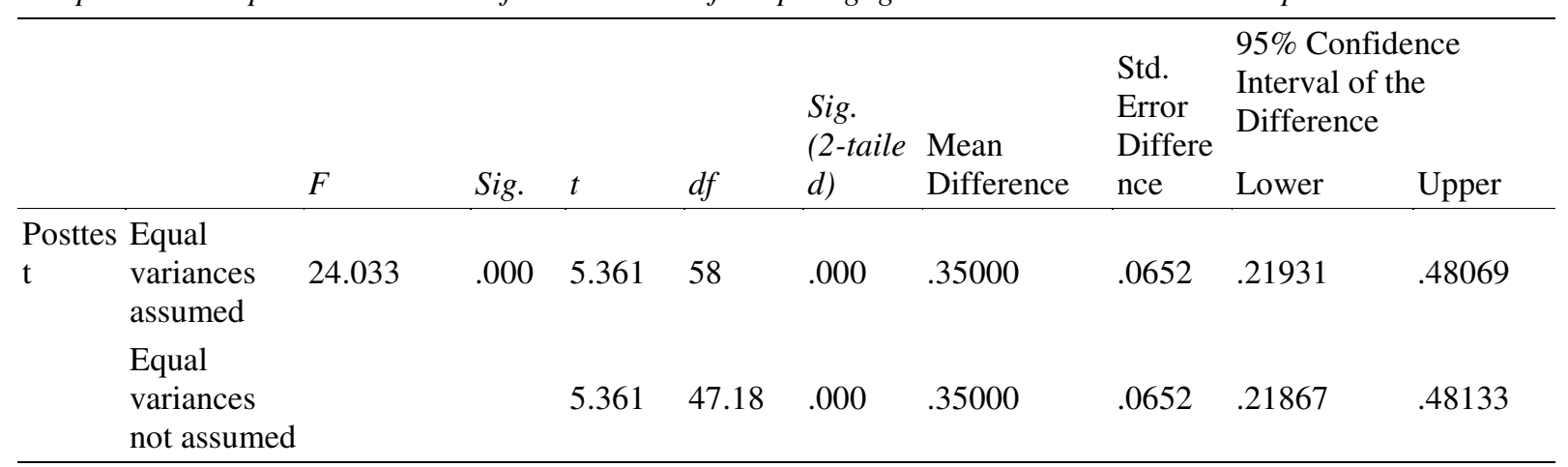

Table 6 shows that there is a significant difference in the scores obtained from the two groups of learners on the posttest $(\mathrm{t}=5.361, \mathrm{p}=.000)$ and the delayed posttest $(4.400, p=.002)$. Accordingly, the 2 nd null hypothesis was rejected because using unedited movies proved to produce better results on the listening comprehension improvement of the learners compared to the pedagogical ones.

\section{Discussion and conclusion}

The results of data analyses for all groups for the first null hypothesis stating "there are no effects for a self-regulatory approach on the listening comprehension achievement of High and Low Skilled learners" revealed that both High and Low Skilled participants of experimental groups, being compared at the beginning- 
The effects of a self-regulatory approach on the listening comprehension achievement of EFL learners

and the end-of-study, achieved a significant improvement on their post-test performance. Both High and Low Skilled groups had a noticeable progress after the treatment. Besides, using a follow up ANOVA for the Pre and Post-test, the researcher found a better improvement rate for the Low Skilled experimental groups. In the pre-test data analysis, the High Skilled groups outperformed the Low Skilled ones, while on the post test, the Low skilled groups had a slightly better mean score (although not significantly). This can attest the greater improvement on the part of the Low Skilled groups as the low skilled participants managed to fill in the gap and catch up with their high skilled counterparts.

This can indicate that teaching listening comprehension via a self-regulatory approach can result in better language learners who will learn to orchestrate their listening comprehension process better (Goh, 2000). The results may be attributed to the fact that less proficient language learners face more difficulty managing their process of language learning, specifically in listening comprehension, and when they are taught how to do so, they can experience a noticeable improvement (Vandergrift \& Goh, 2012). Hence, it can be claimed that the treatment, the self-regulatory listening approach, nurtured the development of this ability in the Low Skilled learners to a greater extent. The findings are also in agreement with Liu and Goh's (2006) empirical results. Similar to our study, the low-proficiency learners in Liu and Goh's study benefited the most in their improvement of metacognitive awareness and self-regulatory abilities which, in turn, resulted in better listening comprehension ability in general.

Due to their greater understanding of the strengths and weaknesses coupled with the greater awareness of the necessities of the process of listening comprehension, the experimental group subjects made some amendments to the way they used to approach a listening text to improve their understanding. Via a self-regulatory approach, learners will learn how to work on their weaker sides and be in charge of their learning process. This is in line with Goh and Taib's (2006) study who reported a better improvement rate for the listening ability of their young participant in general after a similar self-regulatory listening treatment. Go and Taib attributed their young participants success to their improvement in handling the listening process more efficiently, which was once again more noticeable for the weaker students. The findings are also consistent with Vandergrift (2004) who discovered that being aware of such metacognitive strategies helped the less skilled learners to process information better.

The augmented self-regulatory abilities found among the participants of this study supports Vandergrift (2003b, p. 435) that "consciousness-raising activities can encourage students to take on the responsibility for planning, monitoring, and evaluating their own learning". In addition, the findings also lend support to Wenden's (1999) idea that: "In learning transfer, metacognitive knowledge facilitates the appropriate choice of previously learned strategies to achieve learning goals and/or to deal with problems encountered during the learning" (Wenden, 1999, p. 526).

Despite the large body of literature supporting the improvement of the participants, a metacognitive or self-regulatory approach was not always supported in the literature. For instance, no clear positive results were reported in the comprehension rate of English students in Japan in a study conducted by Ozeki's (2000). In another study by O'Malley et al. (1985), the observed results were not also significantly meaningful. Besides, McGruddy (1995) found statistically meaningful results comparing the results of a pretest-posttest on a non-standardized listening test, whereas the same results were not achieved in a standardized test which is contrary to the findings of the present study. Finally, in a research carried out by Cross (2009) on some young Japanese language learners, no significant improvement was also recorded which is quite the opposite of the findings of the present study.

Our second research question concerned whether there is any differences between using unedited (authentic) materials and pedagogical materials in terms of their effects on the overall listening comprehension ability. The results demonstrated that integrating authentic listening materials into L2 classrooms can exercise a positive effect on the listening comprehension ability of L2 learners. 
The rationale for the findings may be explained by 2 factors. First, it can possibly be the inherent difference between the kind of language which is used in pedagogical and real-life situations (Crystal \& Davy 1975). According to Widdowson (1983), the simplified listening texts are doctored to fit the proficiency levels of the learners and this makes the language unnatural. In contrast, unedited materials are best suited to achieve comprehension of every day speech, because they reflect real-life listening, and allow for exposure to different varieties of language (Vandergrift, 2007). Therefore, according to Blanco (2002) the exposure to the natural use of language and working on every day conversation may explain the better performance of the unedited movie type groups on the post test.

Secondly, a self-regulatory approach helps learners achieve the know-how knowledge of dealing with ungraded materials (Vandergrift, 2010). In line with Hulstijn (2003), instructing learners not to listen to every single word helps them to avoid overloading their short term memory, which consequently, can lead to better comprehension. This is in agreement with Rubin (1990), arguing that if unedited materials are taught along with some guidelines and strategy training by the teacher, the learner can gain greater improvements. Therefore, the findings support the earlier evidence that listening practice with unedited (authentic) materials has merits (Vandergrift, 2007). In accordance with Herron (1995), it was found that exposure to authentic materials can lead to a further gain for the learners.

\section{Pedagogical Implications}

\subsection{Implications for EFL Teachers}

Considering the beneficial impacts of drawing learners' attention to more practices of listening skill, EFL teachers are expected to invest more time in teaching listening skill. Such an approach can be achieved through the use of a self-regulatory approach and using authentic materials. For example, teachers should instruct learners to focus attentively while the listening texts is being played and instruct them not to occupy their short term memory by too much focus on details. Teachers should train students to avoid word by word translation and tell them to keep on listening to all parts even if the text proved difficult to understand. Learners should also be taught how to systematically question and double-check the words they guess. Moreover, they should be trained to use their back ground knowledge to enhance their comprehension.

Teachers can also use authentic listening materials as a part of everyday classes for every level with every kind of learners. However, the kind of task we expect from them must differ according to learners' proficiency level. Although teaching listening is hard to implement and seems to be cumbersome to any teacher, it is an attractive teaching method for those teachers who believe in activeness of LC, and for those who prefer a more interactive approach as well. Teachers are expected to use a self-regulatory approach in teaching listening comprehension according to learners' level of language proficiency.

\subsection{Implications for EFL Learners}

It is suggested that learners, both High and Low skilled, use the instructor-directed reinforcement and activities conducted immediately after the repeated listening. These activities along with further discussions of the comprehension difficulties encountered can help the improvement of learners' self-regulatory ability. This, in turn, will enable them to become more independent and take charge of their learning process. Via a self-regulatory approach and exposure to unedited listening materials, learners can keep themselves motivated when encountering a difficulty in their listening comprehension (affective factor) as they are more aware of their strengths and weaker sides and are trained to do so. By being aware of their problems, L2 listeners can use their strengths to compensate for their shortcomings. For instance, when a comprehension breakdown occurs, an L2 listener can use his training to keep on listening to the rest of the text and not to get distracted as s/he knows that the main points will be repeated throughout the text. 


\subsection{Implications for Materials Developer}

The results of this study showed that using authentic materials for listening comprehension can be beneficial to improve listening comprehension. Therefore, materials developers are recommended to utilize authentic materials for listening comprehension activities in their materials. Incorporating authentic materials can especially be cooperative for EFL listeners, and compensate for learners' lack of exposure to the real life situation, thus, it can lead to a more appropriate condition for listening comprehension improvement.

\section{References:}

Anderson, J. R. (1985). Cognitive psychology and its implications (2 $2^{\text {nd }}$ ed). New York: HFreeman.

Blanco, B. (2002). The role of linguistic input in language acquisition: A listening comprehension based study considering the input limitations of the EFL environment. Unpublished Doctoral dissertation, Indiana University.

Cohen, A. D. (2000). Strategies in Learning and Using a Second Language. Foreign Language Teaching and Research Press.

Cohen, A. D. (2007). Coming to terms with language learner strategies: Surveying the experts. In A. D. Cohen \& E. Macaro (Eds.), Language learner strategies: 30 years of research and practice (pp. 29-45). Oxford: Oxford University Press.

Cohen, A. D., \& Macaro, E. (Eds.) (2007). Language learner strategies: Thirty years of research and practice. Oxford: Oxford University Press.

Cross, J. D. (2009b). The development of metacognition of L2 listening in joint activity. Unpublished Doctoral dissertation, University of Melbourne, Australia.

Crystal, D., \& Davy, D. (1975). Advanced conversational English. Harlow: Longman.

Fatemi, A. H., \& Vahidnia, F. (2014). Students' educational level and their goal choices, self-efficacy, motivation, and writing performance. International Journal of Research Studies in Education, 3(2), 112-127.

Goh, C. (1997). Meta-cognitive awareness and second language listeners. ELT Journal, 51, 361-369. http://dx.doi.org/10.1093/elt/51.4.361

Goh, C. (2000). A cognitive perspective on language learners' listening comprehension problems. System, 28 , 55-75. http://dx.doi.org/10.1016/S0346-251X(99)00060-3

Goh, C. (2002). Exploring listening comprehension tactics and their interaction patterns. Systems, 30,185-206. http://dx.doi.org/10.1016/S0346-251X(02)00004-0

Goh, C. (2008). Meta-cognitive instruction for second language listening development: Theory, practice and research implications. RELC Journal, 39, 188-213. http://dx.doi.org/10.1177/0033688208092184

Goh, C., \& Taib, Y. (2006). Meta-cognitive instruction in listening for young learners. ELT Journal, 60, 222-232. http://dx.doi.org/10.1093/elt/ccl002

Graham, S., \& Macaro, E. (2008). Strategy instruction in Listening for lower intermediate learners of French. Language learning, 58(4), 747- 783. http://dx.doi.org/10.1111/j.1467-9922.2008.00478.x

Herron, C. (1995). A comparison study of the effects of video-based versus text-based instruction in the foreign language classroom. The French Review, 68(5), 775-795.

Hulstijn, J. H. (2003). Connectionist models of language processing and the training of listening skills with the aid of multimedia software. Computer Assisted Language Learning, 16(5), 413-425. http://dx.doi.org/10.1076/call.16.5.413.29488

Jensen, E. D., \& Vinther, T. (2003). Exact repetition as input enhancement in second language acquisition. Language Learning, 53, 373-428. http://dx.doi.org/10.1111/1467-9922.00230

Mareschal, C. (2007). Student perceptions of a self-regulatory approach to second language listening comprehension development. Unpublished Doctoral dissertation, University of Ottawa, Canada.

Latifi, M., Youhanaee, M., \& Mohammadi, E. (2013). Simplifying the text or simplifying the task: How to improve listening comprehension. Porta Linguarum, 19, 7-21.

McGruddy, R. (1998). The effect of listening comprehension strategy training with advanced level ESL students. 
Latifi, M., Tavakoli, M., \& Dabaghi, A.

Dissertation Abstracts International, 59, 4416, (UMI No. 9916234).

Jones, B., Palincsar, A., Ogle, D., \& Carr, E. (Eds.). (1987). Strategic teaching and learning: Cognitive instruction in the content areas. Alexandria, VA: Association for Supervision and Curriculum Development.

O'Malley, J., \& Chamot, A. (1990). Learning strategies in second language acquisition. Cambridge, England: Cambridge University Press. http://dx.doi.org/10.1017/CBO9781139524490

Oxford, R. (2011). Self-regulation update on L2 listening. LT, 21, 205-211.

Ozeki, N. (2000). Listening strategy instruction for female EFL college students in Japan. Tokyo: Macmillan Language House.

Rubin, J. (1975). A review of second language listening comprehension research. The Modern Language Journal, 78, 199-221. http://dx.doi.org/10.1111/j.1540-4781.1994.tb02034.x

Rubin, J. (1990). Improving foreign language listening comprehension”. In Alatis, J. E. (Ed.) Georgetown University Round Table on Languages and Linguistics 1990. Washington, D.C.: Georgetown University Press.

Vaez Dalili, M., \& Tavakoli, M. (2013). A comparative analysis of reading strategies across ESP students of humanities and engineering. International Journal of Research Studies in Language Learning, 2(5), 63-78. http://dx.doi.org/10.5861/ijrsll.2013.257

Vandergrift, L. (1997). The strategies of second language (French) listeners: A descriptive study. Foreign Language Annals, 30, 387-409. http://dx.doi.org/10.1111/j.1944-9720.1997.tb02362.x

Vandergrift, L. (1999). Facilitating second language listening comprehension: acquiring successful strategies. ELT Journal, 53(3), 168-176. http://dx.doi.org/10.1093/elt/53.3.168

Vandergrift, L. (2002). It was nice to see that our predictions were right. Developing meta-cognition in L2 listening comprehension. Canadian Modern Language Review, 58, 555-575. http://dx.doi.org/10.3138/cmlr.58.4.555

Vandergrift, L. (2003a). Orchestrating strategy use: Toward a model of the skilled second language listener. Language Learning, 53, 463-496. http://dx.doi.org/10.1111/1467-9922.00232

Vandergrift, L. (2003b). From prediction to reflection: Guiding students through the process of L2 listening. Canadian Modern Language Review, 59, 425-440. http://dx.doi.org/10.3138/cmlr.59.3.425

Vandergrift, L. (2005). Relationships among motivation orientations, meta-cognitive awareness and proficiency in L2 listening. Applied Linguistics, 26, 70-89. http://dx.doi.org/10.1093/applin/amh039

Vandergrift, L., Goh, C., Mareschal, C., \& Tafaghodtari, M. H. (2006). The Meta-cognitive Awareness Listening Questionnaire (MALQ): Development and validation. Language Learning, 56, 431-462. http://dx.doi.org/10.1111/j.1467-9922.2006.00373.x

Vandergrift, L. (2007). 'Recent developments in second and foreign language listening comprehension research'. Language Teaching, 60(2), 470-497.

Vandergrift, L., Tafaghodtari, M. (2010). Teaching L2 learners how to listen does make a difference: an empirical study. Language Learning, 40, 191-210.

Vandergrift, L., \& Goh, C. (2012). Teaching and Learning Second Language Listening: Metacognition in Action. New York: Routledge.

Wenden, A. (1999). An introduction to metacognitive knowledge and beliefs in language learning: beyond the basics. System, 27, 435-441. http://dx.doi.org/10.1016/S0346-251X(99)00043-3

Widdowson, H. G. (1983). Learning purpose and language use. Oxford: Oxford University Press. 